\title{
PELAKSANAAN UNDANG-UNDANG NOMOR 33 TAHUN 2014 TENTANG JAMINAN PRODUK HALAL TERHADAP PENDAFTARAN SERTIFIKAT HALAL PADA PRODUK MAKANAN
}

\author{
Melissa Aulia Hosanna \\ (Mahasiswa Program S1 Fakultas Hukum Universitas Tarumanagara) \\ (E-mail: melissahosana@yahoo.com)
}

\section{Susanti Adi Nugroho}

(Corresponding Author)

(Dosen Hukum Perlindungan Konsumen Fakultas Hukum Universitas Tarumanagara, Meraih Sarjana Hukum (S.H.) dari Fakultas Hukum Universitas Diponegoro, Magister Hukum (M.H.) dari Fakultas Hukum Universitas Pelita Harapan, Doktor Hukum (Dr.) dari Fakultas Hukum

$$
\text { Universitas Padjajaran) }
$$

(E-mail: susanti_nugroho@yahoo.com)

\begin{abstract}
Food is one of the most necessary needs of humans to survive so that everyone is expected to pay more attention to the food products that will be consumed.Indonesia is a country with a predominantly Muslim population. In the teachings of Islam there are orders to consume halal food and prohibition to consume illegitimate food. Halal product is a product that qualifies halal according to Islamic syariat from its substance, its process and its storage and presentation. This study aims to determine the implementation of law number 33 of 2014 on the guarantee of halal products on the registration of halal certificates on food products and what are the constraints faced in registering halal certificates.The guarantee of consumer protection against the circulation of halal labeled food products is already guaranteed according to the prevailing laws and regulations and the products labeled official halal have provided legal certainty to the halal nature of the product itself which can be seen from the authority given by the government to MUI and $B P J P H$.
\end{abstract}

Keywords: Halal Product, Consumer Protection 


\section{Pendahuluan}

\section{A. Latar Belakang}

Makanan adalah segala sesuatu yang berasal dari sumber hayati dan air, baik yang diolah maupun tidak diolah, yang diperuntukkan sebagai makanan atau minuman bagi konsumsi manusia, termasuk bahan tambahan pangan, bahan baku pangan, dan bahan lain yang digunakan dalam proses penyiapan, pengolahan, dan/atau pembuatan makanan dan minuman. ${ }^{1}$

Makanan halal adalah pangan yang tidak mengandung unsur atau bahan yang haram atau dilarang untuk dikonsumsi umat Islam, baik yang menyangkut bahan baku pangan, bahan tambahan pangan, bahan bantu dan bahan penolong lainnya termasuk bahan pangan yang diolah melalui proses rekayasa genetika dan iradiasi pangan, dan yang pengelolaannya dilakukan sesuai dengan ketentuan hukum agama Islam. ${ }^{2}$ Sedangkan produksi pangan adalah kegiatan atau proses menghasilkan, menyiapkan, mengolah, membuat, mengawetkan, mengemas, mengemas kembali dan/atau mengubah bentuk pangan.

Perlindungan konsumen merupakan bagian yang tak terpisahkan dari kegiatan bisnis yang sehat. Dalam kegiatan bisnis yang sehat terdapat keseimbangan perlindungan hukum antara konsumen dan produsen. Masalah perlindungan konsumen tidak akan pernah habis dan akan selalu menjadi bahan perbincangan di masyarakat. Selama masih banyak konsumen dirugikan, masalahnya tidak akan pernah tuntas. Oleh karena itu, masalah perlindungan konsumen perlu diperhatikan. Hak konsumen yang diabaikan oleh pelaku usaha perlu dicermati secara seksama. Di era globalisasi perkembangan perekonomian terutama di bidang perindustrian dan perdagangan nasional sekarang, telah menghasilkan berbagai bentuk barang dan jasa yang dapat dikonsumsi. Kondisi ini pada satu pihak menguntungkan konsumen, karena kebutuhan konsumen akan

\footnotetext{
${ }^{1}$ Indonesia, Undang-Undang Nomor 18 Tahun 2002 tentang Pangan (Lembaran Negara Republik Indonesia Tahun 2012 Nomor 227), pasal 1 angka 1.

${ }^{2}$ Indonesia, Peraturan Pemerintah Republik Indonesia Nomor 69 Tahun 1999 tentang Label dan Iklan Pangan (Lembaran Negara Republik Indonesia Tahun 1999 Nomor 131), pasal 1 angka 5 .
} 
barang dan jasa yang diinginkan dapat terpenuhi, serta semakin lebar kebebasan konsumen untuk memilih aneka jenis dan kualitas barang dan jasa sesuai dengan kemampuan konsumen. Di lain pihak, kondisi tersebut mengakibatkan kedudukan konsumen dengan pelaku usaha tidak seimbang dan konsumen berada diposisi yang lemah. Konsumen hanya menjadi objek yang tidak mempunyai kekuatan mandiri untuk menimbang suatu barang dan jasa. Ketika mendapati masalah, biasanya konsumen hanya diam. Sementara itu, pelaku usaha lebih tau persis keadaan, kondisi dan kualitas barang yang dihasilkan. ${ }^{3}$

Butir pertama dari Pancasila adalah Ketuhanan Yang Maha Esa yang secara filosofis mencerminkan bahwa Negara Kesatuan Republik Indonesia menjamin kemerdekaan penduduk untuk memeluk agama dan menjamin agar dapat beribadat menurut agama dan kepercayaannya itu, dan sesuai dengan syariat Islam, memerintahkan umatnya agar dari segi makanan dan barang gunaan memakan atau menggunakan bahan-bahan yang baik, suci, dan bersih. UndangUndang Dasar Negara Republik Indonesia Tahun 1945 mengamanatkan negara menjamin kemerdekaan tiap-tiap penduduk untuk memeluk agamanya masingmasing dan untuk beribadah menurut agamanya dan kepercayaannya itu, oleh karena itu negara berkewajiban memberikan perlindungan dan jaminan tentang kehalalan produk yang dikonsumsi dan digunakan masyarakat, dan karena produk yang beredar di masyarakat belum semua terjamin kehalalannya. Oleh karena itu dibentuklah suatu peraturan perundang-undangan mengenai kehalalan suatu produk, dan lahirlah Undang-Undang Nomor 33 Tahun 2014 tentang Jaminan Produk Halal.

Indonesia merupakan negara dengan penduduk yang mayoritas beragama Islam. Dalam ajaran agama Islam terdapat perintah untuk mengkonsumsi makanan yang halal dan larangan untuk mengkonsumsi makanan yang haram. Agama Islam dengan jelas telah memperkenalkan konsep halal terhadap para konsumen muslim agar tidak membiarkan dirinya mengkonsumsi produk

${ }^{3}$ N.H.T. Siahaan, Hukum Konsumen: Perlindungan Konsumen dan Tanggungjawab Produk (Jakarta: Pantai Rei, 2005), 36-37. 
makanan yang tidak jelas bahan yang terkandung didalamnya maupun cara pembuatannya. Kelalaian sebagian umat Islam terhadap kehalalan suatu produk yang dimanfaatkannya dapat memberikan dampak negatif yang panjang. ${ }^{4}$ Oleh karena itu, tentunya diperlukan perhatian yang besar terhadap produk makanan yang beredar bebas di pasaran terutama dari sisi kehalalannya.

Kehalalan suatu produk menjadi kebutuhan yang wajib bagi umat muslim, baik itu pangan, obat-obatan maupun barang-barang konsumsi lainnya. Produk halal tidak hanya diminati oleh masyarakat muslim tetapi juga non muslim, sebab makanan yang halal itu sudah pasti sehat. Banyaknya produk-produk yang belum bersertifikat halal mengakibatkan konsumen, terutama konsumen muslim sulit untuk membedakan produk mana yang benar-benar halal dan dapat dikonsumsi sesuai dengan syariat Islam dengan produk yang tidak halal.

Dalam konteks Indonesia, perlindungan makanan menjadi standar yang perlu dipenuhi. Hal ini karena produk makanan yang terdistribusi akan diserap oleh pasar yang mayoritas konsumennya adalah pemeluk agama dan kepercayaannya tertentu yang mewajibkan pemeluknya untuk mengkonsumsi makanan tertentu. Indonesia dengan mayoritas penduduk muslim yang diwajibkan untuk mengkonsumsi produk makanan halal, atau juga pemeluk agama Buddha yang tidak boleh memakan olahan daging sapi dan sebagainya. Oleh karena itu, informasi tentang kandungan produk makanan serta informasi kehalalan produk menjadi standar makanan sebelum didistribusikan kepada masyarakat.

Labelisasi produk dengan menggunakan stiker halal merupakan salah satu fenomena penting yang tidak hanya menandai bangkitnya kesadaran nilai-nilai etika dan spiritual dalam ranah bisnis dan perilaku bisnis produsen, tetapi juga menunjukkan adanya kepedulian produsen terhadap kemaslahatan konsumen. Fenomena halalisasi produk ini menjadi trend bisnis baik dalam skala internasional, nasional maupun lokal. ${ }^{5}$ Produk yang disebutkan dalam UUJPH adalah barang dan/atau jasa yang terkait dengan makanan, minuman, obat, 
kosmetik, produk kimiawi, produk biologi, produk rekayasa genetik, serta barang gunaan yang dipakai, digunakan, atau dimanfaatkan oleh masyarakat.

Label halal mengandung aspek yuridis untuk memberikan perlindungan konsumen. Artinya secara hukum mencantumkan label halal berarti melindungi konsumen dan melaksanakan undang-undang perlindungan konsumen. Dalam Pasal 4 Undang-Undang Nomor 8 Tahun 1999 tentang Perlindungan Konsumen, terdapat sejumlah hak konsumen yang dilindungi hukum, diantaranya yaitu: Pertama, hak atas kenyamanan dan keselamatan dalam mengkonsumsi barang dan jasa. Kedua, hak untuk memilih barang atau jasa serta kesesuaiannya antara barang dan jasa dengan nilai tukar, dan yang tak kalah penting jaminan yang dijanjikan. Ketiga, hak mendapatkan informasi yang benar, jelas dan jujur mengenai kondisi dan jaminan barang yang digunakan. Keempat, hak untuk mendapatkan kompensasi atau ganti rugi jika barang atau jasa yang diterima tidak sesuai dengan perjanjian atau sebagaimana mestinya. ${ }^{6}$

Produk makanan yang beredar di Indonesia sangat penting sekali terdapat nama produk dan label halal dari Badan Penyelenggara Jaminan Produk Halal (BPJPH), sebab konsumen akan memahami bagaimana memilih produk berlabel halal yang benar-benar terjamin kehalalannya. Pada akhirnya konsumen muslim akan lebih memilih produk yang sudah berlabel halal resmi dibandingkan dengan produk yang tidak ada label halalnya. Banyaknya produk makanan yang tidak berlabel halal sangatlah meresahkan masyarakat, karena kehalalan suatu produk menjadi tolak ukur masyarakat sebagai konsumen untuk membeli suatu barang yang akan dibelinya. Dalam Undang-Undang Nomor 33 Tahun 2014 tentang Jaminan Produk Halal Pasal 33 ayat (1) dijelaskan bahwa penetapan kehalalan produk dilakukan oleh Majelis Ulama Indonesia (MUI) melalui Sidang Fatwa Halal.

Jaminan akan produk halal menjadi suatu yang penting untuk mendapatkan perhatian dari negara, maka pada tanggal 6 Januari tahun 1989 melalui Surat Keputusan Dewan Pimpinan Pusat Majelis Ulama Republik Indonesia Nomor 
018/MUI/I1989 dibentuklah Lembaga Pengkajian Pangan, Obat-obatan, dan Kosmetika Majelis Ulama Indonesia atau yang disebut LPPOM-MUI, dengan tugas:

a. Mengadakan inventarisasi, klasifikasi, dan pengkajian terhadap kehalalan makanan, obat-obatan dan kosmetika yang beredar di masyarakat.

b. Menyampaikan hasil-hasil pengkajian dan konsep-konsep itu kepada Dewan Pimpinan Majelis Ulama Indonesia sebagai bahan pertimbangan dalam perumusan kebijakan yang berkaitan dengan pengelolaan, jual beli dan penggunaan pangan, obatobatan dan kosmetika.

c. Mengadakan berbagai kegiatan dalam rangka menjalin kerjasama dengan instansi-instansi pemerintah dan swasta, dalam dan luar negeri.

Disisi lain, meningkatnya kesadaran masyarakat terhadap produk halal, tidak diimbangi dengan tindakan para pelaku usaha dalam memberikan informasi produk yang tepat atau mensertifikatkan kehalalan produksinya dan memberikan label halal pada kemasannya. Pengertian pelaku usaha dalam Undang-Undang Perlindungan Konsumen adalah setiap orang perseorangan atau badan usaha, baik yang berbentuk badan hukum maupun bukan badan hukum yang didirikan dan berkedudukan atau melakukan kegiatan dalam wilayah hukum negara Republik Indonesia, baik sendiri maupun bersama-sama melalui perjanjian menyelenggarakan kegiatan usaha dalam berbagai bidang ekonomi. Kewajiban mencantumkan informasi makanan, seperti yang telah dijelaskan dalam UndangUndang Perlindungan Konsumen bahwa perbuatan yang dilarang bagi pelaku usaha dalam memproduksi dan/atau memperdagangkan barang dan/atau jasa adalah "tidak memasang label atau membuat penjelasan barang yang memuat nama barang, ukuran, berat/isi bersih atau netto, komposisi, aturan pakai, tanggal pembuatan, akibat sampingan, nama dan alamat pelaku usaha serta keterangan lain untuk penggunaan yang menurut ketentuan harus dipasang/dibuat. ${ }^{7}$

Selain produk yang belum bersertifikat, kasus beredarnya makanan tidak halal beberapa tahun ini menambah keresahan konsumen muslim yang berusaha

${ }^{7}$ Indonesia, Undang-Undang Nomor 8 Tahun 1999 tentang Perlindungan Konsumen (Tambahan Lembaran Negara Republik Indonesia Nomor 3821), Pasal 8. 
menjalankan syariat agamanya. Tidak halal dalam artian proses pembuatannya dengan cara-cara yang tidak halal atau makanan berasal dari bahan yang tidak halal atau mengandung bahan-bahan yang tidak halal. Seperti contoh kasus di Madiun, ditemukan mie instan impor tanpa label halal oleh petugas Dinas Perdagangan, Koperasi, dan Usaha Mikro Kabupaten Madiun. Dinas Perdagangan setempat melakukan razia karena makanan tersebut sempat mengundang keresahan sejumlah warga, dan mereka akan berkoordinasi dengan MUI Kabupaten Madiun untuk menindaklanjuti penemuan makanan yang tidak berlabel halal tersebut. $^{8}$

Contoh kasus lainnya, di Bandung, telah ditemukan camilan yang bernuansa pornografi dan tanpa label halal oleh Majelis Ulama Indonesia (MUI) Jawa Barat. Majelis Ulama Indonesia (MUI) Jawa Barat menyesalkan adanya camilan bernuansa pornografi dan tidak memiliki label halal yang dikeluarkan oleh Lembaga Pengkajian Pangan, Obat-obatan, dan Kosmetika (LPPOM) MUI Jawa Barat. $^{9}$

Contoh tersebut memperlihatkan gejala lemahnya kedudukan konsumen. Pelaku usaha sering sekali mengabaikan standar dan aturan yang ditentukan dalam Undang-Undang Perlindungan Konsumen, akibatnya dapat merugikan konsumen, misalnya mempromosikan produk yang tidak sesuai dengan isi, kondisi, mutu, komposisi, jaminan, janji atau keterangan yang tertera dalam label atau etiket produk.

Dalam perekonomian, pasar berperan sangat penting khususnya dalam sistem ekonomi bebas/liberal. Pasarlah yang berperan untuk mempertemukan produsen dan konsumen. Konsumen sangat menentukan kedudukan pasar, sebab konsumenlah yang berperan untuk menentukan lalu lintas barang dan jasa. ${ }^{10}$

\footnotetext{
${ }^{8}$ Karta Raharja Ucu, "Makanan Tanpa Label Halal MUI Ditemukan Di Toko Ritel", http://www.republika.co.id/berita/nasional/daerah/17/01/31/oknabd282-makanan-tanpa-labelhalal-mui-ditemukan-di-toko-ritel, diakses tanggal 22 Januari 2018.

${ }^{9}$ Oris Riswan, "MUI: Camilan Mi Bikini Juga Tak Punya Label Halal", https://daerah.sindonews.com/read/1128695/21/mui-camilan-mi-bikini-juga-tak-punya-label-halal1470293338, diakses tanggal 22 Januari 2018.

${ }^{10}$ Suhrawardi K. Lubis, Hukum Ekonomi Islam (Jakarta: Sinar Grafika, 2012), 22.
} 
Hukum perlindungan konsumen dewasa ini mendapat cukup perhatian karena menyangkut aturan-aturan guna mensejahterakan masyarakat, bukan saja masyarakat selaku konsumen saja yang mendapat perlindungan, namun pelaku usaha juga mempunyai hak yang sama untuk mendapat perlindungan, masingmasing ada hak dan kewajiban. Pemerintah berperan mengatur, mengawasi, dan mengontrol sehingga tercipta sistem yang kondusif saling berkaitan satu dengan yang lain, dengan demikian tujuan menyejahterakan masyarakat secara luas dapat tercapai. ${ }^{11}$ Dalam kegiatan bisnis yang sehat terdapat keseimbangan perlindungan hukum antara konsumen dengan produsen. Tidak adanya perlindungan yang seimbang menyebabkan konsumen berada pada posisi yang lemah lebih-lebih jika produk yang dihasilkan oleh produsen merupakan jenis produk yang terbatas, hal ini tentu saja akan merugikan konsumen. Oleh karena itu, Indonesia mengatur mengenai sertifikasi halal dengan tujuan agar kepentingan konsumen dapat terlindungi. Berdasarkan uraian diatas, saya tertarik untuk mengkaji lebih lanjut dan mengadakan penelitian apakah sertifikasi halal rumah makan dan restoran telah memiliki legitimasi yang kuat sebagai bentuk perlindungan terhadap konsumen. Pengertian Letigimasi menurut Kamus Besar Bahasa Indonesia adalah keterangan yang mengesahkan atau membenarkan bahwa pemegang keterangan adalah betul-betul orang yang dimaksud.Berdasarkan uraian di atas penulis tertarik untuk mengkaji dan melakukan penelitian dengan judul:

\section{"PELAKSANAAN UNDANG-UNDANG NOMOR 33 TAHUN 2014 TENTANG JAMINAN PRODUK HALAL TERHADAP PENDAFTARAN SERTIFIKASI HALAL PADA PRODUK MAKANAN".}

\section{B. Perumusan Masalah}

Berdasarkan latar belakang yang telah diuraikan sebelumnya, maka untuk lebih memfokuskan penelitian ini dirumuskan permasalahan sebagai berikut: 2011), 1 .

\footnotetext{
${ }^{11}$ Celina Tri Siwi Kristiyanti, Hukum Perlindungan Konsumen (Jakarta: Sinar Grafika,
} 
1. Bagaimana pelaksanaan Undang-Undang Nomor 33 Tahun 2014 tentang Jaminan Produk Halal terhadap pendaftaran sertifikat halal pada produk makanan?

2. Apa saja kendala-kendala yang terjadi dalam proses pendaftaran sertifikat halal pada produk?

\section{Pembahasan}

\section{A. Pelaksanaan Undang-Undang Nomor 33 Tahun 2014 tentang Jaminan Produk Halal terhadap Pendaftaran Sertifikat Halal pada Produk Makanan}

Banyaknya produk yang tidak berlabel halal membuat konsumen terutama konsumen muslim menjadi kesulitan untuk memilih produk mana yang benarbenar terjamin kehalalannya sesuai dengan syariat Islam. Perlunya perlindungan hukum dari pemerintah untuk konsumen muslim membuat lahirnya UndangUndang Nomor 33 Tahun 2014 Tentang Jaminan Produk Halal menjadi sesuatu yang sangat penting.

Sebuah kasus yang menghebohkan terjadi tahun 1988, Buletin Canopy edisi Januari tahun ini yang diterbitkan oleh Senat Mahasiswa Fakultas Peternakan Universitas Brawijaya (UB) - Malang memuat tulisan berupa laporan penelitian Ir. Tri Susanto, M.App.Sc yang menyatakan bahwa sejumlah produk makanan dan minuman terindikasi mengandung lemak babi. Saat ini almahrum adalah mantan guru besar Teknologi Pangan Universitas Brawajiya Malang.

Tulisan tersebut telah menimbulkan kepanikan masyarakat baik dari kalangan konsumen muslim khususnya, maupun kalangan produsen produk pangan. Sejumlah produsen mengalami penurunan omset secara drastis. PT Sanmaru Food Manufacture, produsen Indomie mengaku penjualannya turun 2030 persen dari omzet 40 juta bungkus perbulannya. Penjualan Kecap ABC 
melorot hingga 20 persen, dan Es Krim Campina yang sempat dikait-kaitkan dengan penelitian tersebut turun hingga 40 persen. $^{12}$

Produsen Biskuit Siong Hoe, PT Tri Fabig terpaksa harus gencar mengiklankan diri bila produknya tidak haram. PT Food Specialties Indonesia (FSI) terpaksa juga mengeluarkan dana iklan Rp 340 juta, jumlah yang cukup besar ketika itu.

Fenomena sebagaimana di atas menyadarkan berbagai pihak bahwa keberadaan jaminan halal untuk produk-produk konsumsi menjadi suatu kebutuhan yang mendesak bagi umat Islam. Seperti disampaikan oleh Profesor Amin Aziz ketua LPPOM MUI periode pertama, anggapan bahwa jika umat Islam mayoritas pasti masalah halal akan terjamin ternyata tidak otomatis, sehingga dibutuhkan adanya kebijakan yang mengatur.

Kebutuhan jaminan produk halal telah menjadi isu penting di Indonesia. Umat Islam yang menjadi penduduk mayoritas dengan jumlah sekitar $86 \%$ bisa terusik dengan isu halal-haram ini sehingga menuntut adanya penyikapan dari pemerintah.

Sekalipun demikian pemerintah ketika itu tidak segera mengambil kebijakan cepat menyikapi fenomena tersebut. Sikap yang dilakukan pemerintah justru berusaha menetralisir masalah dengan secara yang kurang proporsional. Seperti yang ditampilkan oleh Sekjen Departermen Agama (ketika itu) Tarmidzi Taher, yang secara demonstratif meminum susu di sebuah pabrik di Pasuruan untuk diinput oleh media dengan maksud meredam gejolak di masyarakat.

Majelis Ulama Indonesia (MUI) yang menyatakan dalam pedoman organisasinya sebagai wadah musyawarah para ulama, para zuama (pemimpin), dan cendekiawan muslim akhirnya yang mengambil inisiatif untuk melakukan sejumlah pertemuan membahas masalah tersebut. Upaya yang dilakukan oleh MUI tidak lepas dari dorongan para intelektual muslim dan para ulama.

$$
40 .
$$

${ }^{12}$ Aisjah Girindra, Pengukir Sejarah Sertifikasi Halal (Jakarta: LPPOM MUI, 2005), 39- 
MUI merupakan organisasi non pemerintah tetapi karena sifatnya sebagai organisasi forum lintas ormas, keberadaannya dipandang strategis sehingga mempunyai kedekatan khusus dengan pemerintah. Dari pertemuan-pertemuan yang diselenggarakan MUI ini akhirnya terbentuk Lembaga Pengkajian Pangan, Obat-Obatan, dan Kosmetika, Majelis Ulama Indonesia yang kemudian disingkat LPPOM MUI.

LPPOM MUI berdiri tanggal 6 Januari 1989 berdasarkan Surat Keputusan Majelis Ulama Indonesia Nomor: Kep./18/MUI/I/1989, dengan rencana kegiatan utama melaksanakan pemeriksaan produk halal yang kemudian disebut sertifikasi halal.

Kegiatan sertifikasi halal ini dimaksudkan untuk mendapatkan jaminan produk halal. Proses sertifikasi halal dilakukan dengan cara penelusuran mendalam untuk mengetahui secara pasti apakah bahan-bahan yang digunakan dalam pembuatan suatu produk pangan serta proses produksinya telah terjamin halal dan konsisten atau tidak. Hasil sertifikasi halal adalah diterbitkannya sertifikat halal bila telah memenuhi syarat yaitu pernyataan halal atas suatu produk yang dihasilkan oleh suatu perusahaan berdasarkan hasil audit dan kajian fatwa. Adanya sertifikat halal dimaksudkan agar konsumen muslim terlindungi dari produk-produk yang tidak halal. ${ }^{13}$

Kendatipun LPPOM MUI telah berdiri sejak tahun 1989, namun dalam implementasinya sertifikat halal dikeluarkan pertama kali oleh MUI berdasarkan hasil audit dari LPPOM MUI baru tahun 1994 setelah LPPOM MUI memperoleh persetujuan dari Menteri Agama ketika itu. Selama waktu lima tahun sejak berdiri sampai dapat direalisasikannya kegiatan sertifikasi halal.

Melansir Lembaga Pengkajian Pangan Obat-obatan dan Kosmetika (LPPOM) Majelis Ulama Indonesia (MUI), pembentukan didasarkan atas mandat dari pemerintah agar MUI berperan aktif dalam meredakan kasus lemak babi di

\footnotetext{
${ }^{13}$ Ainul Yaqin, "Sejarah Sertifikasi Halal Di Indonesia", www.hidayatullah.com/kajian/sejarah/read/2017/01/18/109939/sejarah-sertifikasi-halal-diindonesia-1.html, diakses tanggal 25 April 2018.
} 
Indonesia pada tahun 1988. Saat itu, beredar isu mengenai lemak babi di Indonesia. LPPOM MUI didirikan pada tanggal 6 Januari 1989 untuk melakukan pemeriksaan dan sertifikasi halal. Untuk memperkuat posisi LPPOM MUI menjalankan fungsi sertifikasi halal, maka pada tahun 1996 ditandatangani Nota Kesepakatan Kerjasama antara Departermen Agama, Departermen Kesehatan dan MUI. Nota kesepakatan tersebut kemudian disusul dengan penerbitan Keputusan Menteri Agama (KMA) 518 Tahun 2001 dan KMA 519 Tahun 2001, yang menguatkan MUI sebagai lembaga sertifikasi halal serta melakukan pemeriksaan/ audit, penetapan fatwa, dan menerbitkan sertifikat halal.

Majelis Ulama Indonesia (MUI) menetapkan produk halal adalah produk yang memenuhi syarat kehalalan sesuai dengan syariat Islam, dengan rincian tidak mengandung bahan yang bersumber dari babi, bahan-bahan yang berasal dari organ manusia, darah, kotoran dan lain sebagainya. Bahkan yang berasal dari hewan halal tetapi disembelih tidak sesuai dengan tata cara syariat Islam. ${ }^{14}$ Adapun yang menjadi syarat produk pangan halal menurut syariat Islam adalah: 1) halal zatnya, 2) halal dalam memperolehnya, 3) halal dalam memprosesnya, 4) halal dalam penyimpanannya, 5) halal dalam pengangkutannya, dan 6) halal dalam penyajiannya. Pemeriksaan suatu produk halal dilakukan oleh sebuah Lembaga Pengkajian Pangan, Obat-obatan, dan Kosmetika Majelis Ulama Indonesia (LPPOM) yang dibentuk oleh MUI dan ditetapkan oleh Menteri Agama setelah diakreditasi oleh Komite Akreditasi Nasional (KAN). Kemudian Komite Halal Indonesia (KHI) bertugas melakukan koordinasi, membuat kajian hasil pemeriksaan lembaga pemeriksa dan membuat rekomendasi kepada Menteri Agama serta MUI. ${ }^{15}$ Produk halal sekarang bukan hanya sebatas untuk kepentingan agama tetapi merupakan sesuatu yang juga penting dalam industri perdagangan. Jaminan terhadap suatu produk terutama produk makanan merupakan tanda bahwa produk yang bersangkutan terjamin kualitasnya.

\footnotetext{
${ }^{14}$ Aisjah Girindra, Op.Cit., 11.

${ }^{15}$ Sofyan Hasan, Sertifikasi Halal Dalam Hukum Positif (Yogyakarta: Aswaja Pressindo, 2014), 146-147.
} 
Konsumen akan cenderung memilih produk makanan berlabel halal, sebab kualitas dari produk halal lebih terjamin kualitas didalamnya.

Pengertian label halal dalam Pasal 1 angka 11 UUJPH adalah tanda kehalalan suatu produk. Produk yang telah dinyatakan halal oleh fatwa halal MUI dalam bentuk putusan fatwa produk halal dalam bentuk Sertifikat Halal, perlu diberi tulisan atau label halal pada kemasannya agar mudah dikenali. Pemberian tanda atau tulisan halal dalam bentuk label halal merupakan upaya perlindungan konsumen muslim sebagai konsumen terbesar di Indonesia. Kewajiban pencantuman label halal dapat membantu konsumen muslim untuk dapat memilih produk yang akan dikonsumsinya. Namun, pencantuman label halal baru dapat dilakukan oleh perusahaan manakala produknya telah mendapatkan Sertifikat Halal dan Nomor Registrasi Halal dari Badan Nasional Penjamin Produk Halal $(\mathrm{BNP} 2 \mathrm{H})$, dan yang menjadi dasar mengikat BNP2H mengeluarkan Sertifikat Halal dan Nomor Registrasi Halal adalah Putusan Fatwa MUI. ${ }^{16}$ Label halal yang ada pada kemasan produk yang beredar di Indonesia adalah sebuah logo yang tersusun dari huruf-huruf Arab yang membentuk kata halal pada sebuah lingkaran. ${ }^{17}$

Sertifikat halal adalah surat keterangan yang dikeluarkan oleh MUI Pusat atau Propinsi tentang halalnya suatu produk makanan, minuman, obat-obatan dan kosmetika yang diproduksi oleh perusahaan setelah diteliti dan dinyatakan halal oleh LPPOM MUI. Pemegang otoritas menerbitkan sertifikasi produk halal adalah MUI yang secara teknis ditangani oleh LPPOM MUI. ${ }^{18}$ Menurut Pasal 29 UUJPH permohonan sertifikat halal diajukan oleh pelaku usaha secara tertulis kepada BPJPH (Badan Penyelenggara Jaminan Produk Halal). Permohonan Sertifikat Halal harus dilengkapi dengan dokumen:

a. Data pelaku usaha;

b. Nama dan jenis produk;

c. Daftar produk dan bahan yang digunakan; dan

\footnotetext{
${ }^{16}$ Ibid., 331-332.

${ }^{17}$ Departemen Agama RI, Petunjuk Teknis Pedoman Sistem Produksi Halal (Jakarta: Departemen Agama RI, 2003), 131.

${ }^{18}$ Sofyan Hasan, Op.Cit.,242.
} 
d. Proses pengolahan produk.

Bagi konsumen, sertifikat halal berfungsi ${ }^{19}$ :

a. Terlindunginya konsumen muslim dari mengonsumsi pangan, obat-obatan, dan kosmetika yang tidak halal;

b. Secara kejiwaan perasaan hati dan batin konsumen akan tenang;

c. Mempertahankan jiwa dan raga dari keterpurukan akibat produk haram;

d. Sertifikasi halal juga akan memberikan kepastian dan perlindungan hukum terhadap konsumen.

Sedangkan bagi pelaku usaha, sertifikat halal mempunyai peran sangat penting, yakni ${ }^{20}$ :

a. Sebagai pertanggungjawaban produsen kepada konsumen muslim, mengingat masalah halal merupakan bagian dari prinsip hidup muslim;

b. Meningkatkan kepercayaan dan kepuasan konsumen;

c. Meningkatkan citra dan daya saing perusahaan;

d. Sebagai alat pemasaran serta untuk memperluas area jaringan pemasaran;

e. Memberi keuntungan pada produsen dengan meningkatkan daya saing dan omzet produksi dan penjualan.

Pencantuman label pada, di dalam, dan atau di kemasan menjadi suatu kewajiban bagi setiap orang yang memproduksi atau memperdagangkan produk pangan di Indonesia. Tujuan dari pencantuman label tersebut merupakan salah satu perwujudan dari pemenuhan hak konsumen untuk dapat memperoleh informasi yang benar, jelas dan jujur mengenai kondisi suatu barang sehingga konsumen dapat memutuskan apakah akan membeli dan/atau mengkonsumsi produk tersebut.

Didalam Undang-Undang Nomor 18 Tahun 2012 tentang Pangan terdapat beberapa Pasal berkaitan dengan masalah kehalalan produk pangan, yaitu dalam Bab VIII Label dan Iklan Pangan. Pasal 97, ayat (1), (2) dan (3). Bunyi Pasal dan penjelasan Pasal tersebut adalah sebagai berikut ${ }^{21}$ :

\footnotetext{
${ }^{19}$ Ibid.

${ }^{20}$ Ibid.

${ }^{21}$ Ibid, 169 .
} 
Pasal 97:

1) Setiap orang yang memproduksi pangan didalam negeri untuk diperdagangkan wajib mencantumkan label di dalam dan/atau pada kemasan pangan.

2) Setiap orang yang mengimpor pangan untuk diperdagangkan wajib mencantumkan label di dalam dan/atau pada kemasan pangan pada saat memasuki wilayah Negara Kesatuan Republik Indonesia.

3) Pencantuman label didalam dan/atau pada kemasan pangan sebagaimana dimaksud pada ayat (1) dan ayat (2) ditulis atau dicetak dengan menggunakan bahasa Indonesia serta memuat paling sedikit keterangan mengenai:

a. Nama produk;

b. Daftar bahan yang digunakan;

c. Berat bersih atau isi bersih;

d. Nama dan alamat pihak yang memproduksi atau mengimpor;

e. Halal bagi yang dipersyaratkan;

f. Tanggal dan kode produksi;

g. Tanggal, bulan, dan tahun kadaluwarsa;

h. Nomor izin edar bagi pangan olahan; dan

i. Asal usul bahan pangan tersebut.

Dengan pencantuman halal pada label pangan, dianggap telah terjadi pernyataan dimaksud dan setiap orang yang membuat pernyataan tersebut bertanggungjawab atas kebenaran pernyataan tersebut.

Dalam pasal 4 UUJPH telah diatur dengan jelas bahwa produk yang masuk, beredar, dan diperdagangkan di wilayah Indonesia wajib bersertifikat halal. Dan apabila pelaku usaha telah memperoleh sertifikat halal maka pelaku usaha wajib mencantumkan label halal terhadap produk yang telah mendapat sertifikat halal sesuai yang diatur dalam Pasal 25 huruf (b) UUJPH.

Namun kenyataannya sekarang ini masih banyak dijumpai produk makanan yang tidak berlabel halal. Salah satu produk makanan tidak berlabel halal yang mudah ditemui di pasaran adalah mi instan impor. Mi instan impor memiliki daya tarik tersendiri bagi kalangan konsumen di Indonesia karena kebanyakan dari mi instan impor memiliki cita rasa yang berbeda dengan mi instan yang berasal dari dalam negeri. Mi instan impor sendiri mempunyai bentuk 
pengemasan yang hampir sama dengan mi instan dalam negeri yaitu dalam bentuk cup maupun dikemas dalam bungkusan plastik.

Salah satu contoh kasus mi instan tidak berlabel halal terjadi di Kediri, Jawa Timur. Jawa Pos Radar Kediri menelisik ke beberapa minimarket di Jalan Soekarno Hatta, Desa Sukorejo, Kecamatan Ngasem, Kediri. Hasilnya, produk buatan Korea dan Tiongkok cukup banyak. Sebagian sudah memiliki cap halal dari Majelis Ulama Indonesia (MUI), tetapi sebagian tidak. Salah satunya, mi instan merek Shin Ramyun, produk dari Tiongkok. Bertulisan Mandarin dan bewarna merah hitam dengan berat 120 gram, mi tersebut tidak memiliki label halal dari MUI. Saat membayar di kasir, petugasnya sama sekali tidak menyampaikan bahwa mi seharga Rp. 9.900 itu tidak memiliki label halal dari MUI. Produk impor tersebut langsung diserahkan kepada pembeli. Artinya, tidak ada pemberitahuan kepada konsumen tentang produk itu. ${ }^{22}$

Sementara itu, Lembaga advokasi halal Indonesia Halal Watch (IHW) mengungkapkan ada 11 produk makanan kemasan impor yang tidak berlabel halal dan beredar di pasaran Indonesia. Direktur Eksekutif IHW Ikhsan Abdullah dalam konferensi pers di Jakarta, Kamis menyebutkan ada produk makanan kemasan impor yang memang tidak ada logo halalnya dan ada pula produk berlabel halal namun diragukan kehalalannya. IHW mengungkapkan 11 produk makanan kemasan impor tanpa label halal dan 17 produk makanan dengan label halal yang diragukan kehalalannya. Sementara produk-produk berlabel halal yang diragukan kehalalannya karena belum mendapatkan pengakuan sertifikasi halal MUI yakni produk dengan logo halal dari Singapura, Malaysia, China, Filipina, Thailand, dan bahkan ada pula label halal MUI palsu. Ikhsan mengimbau kepada masyarakat muslim Indonesia agar menghindari mengonsumsi produk makanan impor yang tidak ada logo halalnya. Selain untuk menghindari konsumsi produk non-halal,

\footnotetext{
${ }^{22}$ Miftakhul F.S, "Mi Instan Tanpa Label Halal Beredar Di Pasaran", www.jawapos.com/read/2017/01/21/103992/mi-instan-tanpa-label-halal-beredar-di-pasaran, diakses tanggal 01 Mei 2018.
} 
juga untuk melindungi produk-produk dalam negeri dari persaingan produkproduk impor. $^{23}$

Kurangnya sosialisasi dari Pemerintah kepada pelaku usaha maupun konsumen merupakan salah satu faktor yang membuat kesadaran pelaku usaha untuk mencantumkan label halal masih rendah. Begitu pula dengan konsumen dalam membeli produk kurang memperhatikan label halal.

Pemerintah memegang peranan penting dalam memberikan jaminan terhadap pengawasan atas peredaran produk tidak berlabel halal. Salah satu upaya yang bisa kita lihat saat ini telah dilakukan oleh Pemerintah adalah dengan membuat Undang-Undang Nomor 33 Tahun 2014 tentang Jaminan Produk Halal (UUJPH).

Pengawasan menjadi suatu bagian yang penting untuk memberikan jaminan produk halal kepada masyarakat. Tanpa dilakukannya pengawasan maka tidak jarang terjadi pencantuman label halal terhadap produk yang dilakukan sendiri oleh pelaku usaha padahal sesungguhnya belum pernah dilakukan audit, penetapan halal maupun mendapatkan sertifikat halal dari lembaga yang berwenang. Hal inilah yang membuat pengawasan itu menjadi sesuatu yang penting agar para pelaku usaha yang melakukan pelanggaran ditindak lanjuti sehingga konsumen menjadi terlindungi.

Didalam Pasal 30 UUPK ketentuan tentang pengawasan menyebutkan bahwa :

1. Pengawasan terhadap penyelenggaraan perlindungan konsumen serta penerapan ketentuan peraturan perundangundangannya diselenggarakan oleh pemerintah, masyarakat, dan lembaga perlindungan konsumen swadaya masyarakat.

2. Pengawasan oleh pemerintah sebagaimana dimaksud pada ayat (1) dilaksanakan oleh Menteri dan atau menteri teknis terkait.

\footnotetext{
${ }^{23}$ Aditya Ramadhan, "IHW : 11 Produk Makanan Impor Tak Berlabel Halal", www.antaranews.com/berita/673940/ihw-11-produk-makanan-impor-tak-berlabel-halal, diakses tanggal 01 Mei 2018.
} 
3. Pengawasan oleh masyarakat dan lembaga perlindungan konsumen swadaya masyarakat dilakukan terhadap barang dan atau jasa yang beredar di pasar.

4. Apabila hasil pengawasan sebagaimana dimaksud pada ayat (3) ternyata menyimpang dari peraturan perundangundangan yang berlaku dan membahayakan konsumen, Menteri dan atau menteri teknis mengambil tindakan sesuai dengan peraturan perundang-undangan yang berlaku.

5. Hasil pengawasan yang diselenggarakan masyarakat dan lembaga perlindungan konsumen swadaya masyarakat dapat disebarluaskan kepada masyarakat dan dapat disampaikan kepada Menteri dan menteri teknis.

6. Ketentuan pelaksanaan tugas pengawasan sebagaimana dimaksud pad aayat (1), ayat (2), dan ayat (3) ditetapkan dengan Peraturan Pemerintah.

Pengawasan adalah salah satu faktor yang memberikan jaminan perlindungan bagi konsumen atas peredaran barang dan atau jasa yang ada di pasaran. Dalam Pasal 50 UUJPH pengawasan dilakukan terhadap:

a. Lembaga Pemeriksa Halal;

b. Masa berlaku Sertifikat Halal;

c. Kehalalan Produk;

d. Pencantuman Label Halal;

e. Pencantuman keterangan tidak halal;

f. Pemisahan lokasi, tempat dan alat penyembelihan, pengolahan, penyimpanan, pengemasan, pendistribusian, penjualan, serta penyajian antara Produk Halal dan tidak halal;

g. Keberadaan Penyelia Halal; dan/atau

h. Kegiatan lain yang berkaitan dengan Jaminan Produk Halal.

Badan Penyelenggara Jaminan Produk Halal (BPJPH) dibentuk menurut UUJPH oleh Pemerintah. Dalam penyelenggaran Jaminan Produk Halal (JPH), BPJPH menurut Pasal 6 UUJPH berwenang:

a. Merumuskan dan menetapkan kebijakan JPH;

b. Menetapkan norma, standar, prosedur, dan kriteria JPH;

c. Menerbitkan dan mencabut Sertifikat Halal dan Label Halal pada Produk;

d. Melakukan registrasi Sertifikat Halal pada produk luar negeri; 
e. Melakukan sosialisasi, edukasi, dan publikasi Produk Halal;

f. Melakukan akreditasi terhadap LPH;

g. Melakukan registrasi Auditor Halal;

h. Melakukan pengawasan terhadap JPH;

i. Melakukan pembinaan Auditor Halal; dan

j. Melakukan kerjasama dengan lembaga dalam dan luar negeri di bidang penyelenggaraan JPH.

Pasal 7 UUJPH menjelaskan dalam melaksanakan wewenang yang diatur dalam Pasal 6 diatas, BPJPH bekerja sama dengan:
a. Kementerian dan/atau lembaga terkait;
b. LPH; dan
c. MUI.

Menurut Pasal 47 ayat 1,2, dan 3 UUJPH produk halal luar negeri yang diimpor ke Indonesia berlaku ketentuan sebagaimana diatur dalam UndangUndang ini. Produk halal sebagaimana dimaksud pad aayat (1) tidak perlu diajukan permohonan sertifikat halalnya sepanjang sertifikat halal luar negeri yang telah melakukan kerjasama saling pengakuan sebagaimana dimaksud dalam Pasal 46 ayat (2). Sertifikat halal sebagaimana dimaksud pada ayat (2) wajib diregistrasi oleh BPJPH sebelum produk diedarkan di Indonesia.

Dilihat dari kasus tersebut diatas, pelaksanaan Undang-Undang Nomor 33 Tahun 2014 tentang Jaminan Produk Halal belum maksimal, karena sampai sekarang ini masih ditemukannya produk-produk yang belum terdapat label halal pada kemasannya. Hal ini sangat berkaitan dengan belum juga diterbitkannya peraturan pemerintah (PP) sebagai peraturan pelaksanaan Undang-Undang Jaminan Produk Halal dimaksud sebagaimana diamanatkan dalam undangundang. Seharusnya dua tahun sejak diundangkan maka PP harus segera diterbitkan sebagai landasan operasional. Keterlambatan penerbitan PP menyebabkan BPJPH tidak dapat melaksanakan tugas dan fungsinya secara maksimal. BPJPH tidak memiliki kewenangan untuk melakukan sistem, menentukan besaran tarif sertifikat halal dan hubungan kerja sama dengan lembaga terkait, yang diberikan mandat kewenangan sesuai undang-undang, yaitu Majelis Ulama Indonesia (MUI). Sesuai dengan Pasal 59 dan 60 Undang-Undang 
Nomor 33 Tahun 2014 tentang Jaminan Produk Halal, bahwa sampai dengan terbitnya BPJPH maka sertifikasi halal tetap dijalankan oleh MUI.

Menurut hasil wawancara penulis terhadap Dr. A.M.Tri Anggraini, S.H.,M.H., selaku Dosen Perlindungan Konsumen dan Wakil Dekan IV Fakultas Hukum Trisakti, Beliau mengatakan, bahwa efektivitas hukum dan sistem hukum belum ada, dikarenakan undang-undang sebenarnya sudah mengamanatkan atau meminta peraturan pemerintah yang merupakan pelaksanaan dari Undang-Undang Jaminan Produk Halal, untuk memerintahkan lembaga yang bernama BPJPH untuk melakukan pengawasan atau membuat regulasi sebagai pelaksanaan dari Undang-Undang Jaminan Produk Halal, namun PP itu sampai sekarang belum ada. $^{24}$

Menurut hasil wawancara lainnya yang dilakukan penulis terhadap Staf Humas \& Kelembagaan LPPOM MUI, Bapak Eko Prames Swara, beliau mengatakan bahwa untuk sekarang ini bahwa karena BPJPH belum berjalan secara optimal atau keseluruhan, jadi yang masih memegang kendali untuk meneliti, mengkaji, menganalisa, dan memutuskan untuk mengeluarkan sertifikat halal melalui fatwa halal MUI masih LPPOM MUI. ${ }^{25}$

\section{B. Kendala-Kendala yang Terjadi Dalam Proses Pendaftaran Sertifikasi Halal pada Produk}

Pemberian sertifikasi halal pada produk makanan pada dasarnya merupakan hal penting dan wajib yang harus diperhatikan oleh para pelaku usaha. Dalam hal ini pemerintah melalui Lembaga Pengkajian Pangan Obat-obatan dan Kosmetika Majelis Ulama Indonesia (LPPOM MUI) dan Badan Penyelenggara Jaminan Produk Halal (BPJPH) telah menghimbau kepada pelaku usaha agar mengurus sertifikasi halal bagi produk-produk yang akan diperjualbelikan pada masyarakat. Namun, tidak semua para pelaku usaha mengurus sertifikasi halal pada produk-

\footnotetext{
${ }^{24}$ Penulis, Wawancara, Ibu A.M. Tri Anggraini Dosen Perlindungan Konsumen Fakultas Hukum Universitas Tarumanagara dan Wakil Dekan IV Fakultas Hukum Universitas Trisakti, (Jakarta: 05 Juni 2018)

${ }^{25}$ Penulis, Wawancara, Bapak Eko Prames Swara Staf Humas \& Kelembagaan LPPOM MUI, (Jakarta: 08 Juni 2018)
} 
produknya, hal ini seperti yang bisa dilihat dari contoh-contoh kasus diatas, dan juga menurut Lembaga Advokasi Halal Indonesia Halal Watch (IHW) mengungkapkan ada 11 produk makanan kemasan impor yang tidak berlabel halal dan 17 produk makanan dengan label halal yang diragukan kehalalannya beredar di pasaran Indonesia.

Menurut hasil wawancara yang dilakukan penulis terhadap Staf Humas \& Kelembagaan LPPOM MUI, Bapak Eko Prames Swara, penulis menanyakan kendala-kendala yang terjadi dalam mendaftarkan sertifikasi halal sehingga banyak para pelaku usaha yang belum mendaftarkan sertifikasi halal pada produknya, beliau mengatakan kalau kendala-kendala yaitu yang pertama adalah dahulu sistem pendaftaran sertifikasi halal masih bersifat manual, jadi banyak UKM yang merasa susah, tetapi karena LPPOM MUI bersifat melayani, maka sebisa mungkin LPPOM MUI akan membantu para UKM yang merasa kesusahan, tetapi itu sudah bukan menjadi kendala lagi karena sekarang pendaftaran sudah bersifat online juga, tetapi kekurangan dari sistem online yakni jika sinyal yang kurang bagus atau website yang mengalami gangguan. Yang kedua, perusahaan-perusahaan atau para pelaku usaha mengeluhkan tentang biaya sertifikasi halal yang cukup mahal, dan pihak LPPOM MUI telah menyampaikan bahwa biaya ini terbilang cukup murah, misalnya kalau usaha kecil, sekitar Rp. 2.000.000,00,- (dua juta rupiah) - Rp. 1.500.000,00,- (satu juta lima ratus ribu rupiah) untuk jangka waktu dua tahun. Yang ketiga, ada beberapa perusahaan yang beranggapan bahwa sertifikasi halal belum penting, dan juga tanpa sertifikat halal produk yang mereka jual tetap laku di pasaran. Jadi menurut Bapak Eko, kendala-kendala teknis diatas juga harus dibarengi dengan kesadaran dari para pelaku usaha untuk mengetahui pentingnya dan wajib mendaftarkan sertifikasi halal pada produk mereka. Jadi sebenarnya kendala yang paling besar yaitu para pelaku usaha belum menyadari dan mempunyai keinginan untuk melakukan sertifikasi halal. $^{26}$

\footnotetext{
${ }^{26}$ Penulis, Wawancara, Bapak Eko Prames Swara Staf Humas \& Kelembagaan LPPOM MUI, (Jakarta: 08 Juni 2018)
} 
Agar kendala-kendala tersebut dapat diminimalisir, maka LPPOM MUI dan BPJPH harus dapat menjamin ketenangan, kenyamanan, dan kepastian bagi pelaku usaha (produsen) yang akan mengajukan permohonan sertifikasi halal, menjamin para pelaku usaha telah memperoleh sertifikasi halal, dan memastikan kemudahan bagi pelaku usaha yang akan memperpanjang sertifikasi halalnya berkaitan dengan telah jatuh tempo. Untuk membantu para pelaku usaha memperoleh sertifikasi, juga memudahkan BPJPH dalam melakukan tugas dan fungsinya dengan baik, maka diperlukan segera minimal tujuh peraturan pemerintah (PP) terkait. Selain hal tersebut, yang sangat penting sifatnya adalah membangun kerja sama yang harmonis antara BPJPH dan MUI sebagai lembaga yang menerbitkan fatwa halal dalam sertifikasi halal. Disinilah pilar MUI sangat penting dalam penyelenggaraan sistem jaminan produk halal.

\section{Penutup}

\section{A. Kesimpulan}

Kesimpulan yang dapat ditarik dari hasil penelitian dan pembahasan diatas adalah sebagai berikut:

Jaminan perlindungan konsumen terhadap peredaran produk makanan berlabel halal adalah sudah terjamin menurut peraturan perundang-undangan yang berlaku. Hal ini sesuai dengan peraturan yang mengatur tentang sertifikat dan labelisasi halal yakni Undang-Undang Nomor 8 Tahun 1999 tentang Perlindungan Konsumen, kemudian Undang-Undang Nomor 18 Tahun 2012 tentang Pangan, dan Undang-Undang Nomor 33 Tahun 2014 tentang Jaminan Produk Halal. Hanya saja pelaksanaan Undang-Undang Jaminan Produk Halal (UU JPH) bisa dibilang belum maksimal, karena sampai sekarang ini peraturan pemerintah (PP) untuk melaksanakan undang-undang tersebut belum ada, sehingga pengaturan sertifikasi halal dapat dikatakan belum mempunyai legitimasi hukum yang kuat. Tetapi sertifikasi halal yang selama ini telah dilakukan oleh Majelis Ulama Indonesia (MUI) melalui LPPOM MUI dan Komisi Fatwa telah berhasil 
membantu pemerintah untuk mencegah dan menanggulangi adanya kecurangan produsen atau importer berbuat melawan hukum.

Adapun kendala-kendala yang terjadi pada saat para pelaku mendaftarkan sertifikasi halal yaitu dahulu sistem pendaftaran masih bersifat manual, sehingga para pelaku usaha atau UKM merasa sulit, biaya untuk melakukan sertifikasi halal yang tergolong cukup mahal, para perusahaan-perusahaan atau para pelaku usaha yang beranggapan bahwa pendaftaran sertifikasi halal belum penting, sehingga jika tidak mendaftar pun, produk-produk yang diperjual-belikan masih tetap laku, dan yang terakhir yaitu kesadaran dan keinginan dari para pelaku usaha untuk melakukan pendaftaran sertifikasi halal. Dan juga peraturan pemerintah (PP) harus segera dibuat agar BPJPH dapat melakukan tugas dan fungsinya dengan baik.

\section{B. Saran}

Bagi Pemerintah dan lembaga terkait yakni LPPOM MUI dan BPJPH haruslah memberikan pendidikan, sosialisasi secara maksimal kepada konsumen dan pelaku usaha mengenai pentinganya sertifikasi halal dan penegakan hukumnya harus diperkuat. Segera membuat dan mengesahkan peraturan pemerintah (PP) agar kepastian hukum mengenai sertifikasi halal dapat terjamin dan segera dilaksanakan. Dan bagi pelaku usaha yang penting adalah menjaga kualitas produknya. Mencantumkan label halal adalah wajib dan bermanfaat bagi pelaku usaha bukan hanya untuk konsumen, tetapi bagi pelaku usaha itu sendiri untuk mendorong suatu kepercayaan dari masyarakat.

Peran BPJPH sebagai pelaksana sertifikasi halal harus memaksimalkan pelaksanaannya dan pendaftaran sertifikat halal agar dipermudah guna para pelaku usaha tidak merasa kesulitan dalam melabel halal produknya. 


\section{Daftar Pustaka}

A. Buku

Departemen Agama RI, PetunjukTeknisPedomanSistemProduksi Halal (Jakarta: Departemen Agama RI, 2003)

Girindra,Aisjah. Pengukir Sejarah Sertifikasi Halal. (Jakarta: LPPOM MUI, 2005)

Hasan,Sofyan. Sertifikasi Halal Dalam Hukum Positif. (Yogyakarta: Aswaja Pressindo, 2014).

Kristiyanti, Celina Tri Siwi. Hukum Perlindungan Konsumen. (Jakarta: Sinar Grafika, 2011)

Lubis, Suhrawardi. K. Hukum Ekonomi Islam. (Jakarta: Sinar Grafika, 2012)

Nuryati,Sri. Halalkah Makanan Anda?. (Solo: Aqwamedika, 2008).

Pelu,Muhammad Ibnu Elmi As. Label Halal. (Malang: Madani, 2009).

Siahaan,N.H.T. Hukum Konsumen: Perlindungan Konsumen dan Tanggungjawab Produk. (Jakarta: Pantai Rei, 2005).

B. Peraturan Perundang-Undangan

Indonesia. Undang-Undang Nomor 8 Tahun 1999 tentang Perlindungan Konsumen (Lembaran Negara Republik Indonesia Tahun 1999 Nomor 42).

Undang-Undang Nomor 18 Tahun 2002 tentang Pangan (Lembaran Negara Republik Indonesia Tahun 2012 Nomor 227). Peraturan Pemerintah Republik Indonesia Nomor 69 Tahun 1999 tentang Label dan Iklan Pangan (Lembaran Negara Republik Indonesia Tahun 1999 Nomor 131)

\section{Internet}

F.S Miftakhul, "Mi Instan Tanpa Label Halal Beredar Di Pasaran", www.jawapos.com/read/2017/01/21/103992/mi-instan-tanpa-labelhalal-beredar-di-pasaran. Diakses tanggal 01 Mei 2018.

Ramadhan Aditya, "IHW : 11 Produk Makanan Impor Tak Berlabel Halal", www.antaranews.com/berita/673940/ihw-11-produkmakanan-impor-tak-berlabel-halal. Diakses tanggal 01 Mei 2018

Riswan Oris. "MUI: Camilan Mi Bikini Juga Tak Punya Label Halal". https://daerah.sindonews.com/read/1128695/21/mui-camilan-mibikini-juga-tak-punya-label-halal-1470293338. Diakses tanggal 22 Januari 2018.

Ucu, Karta Raharja. "Makanan Tanpa Label Halal MUI Ditemukan Di Toko

Ritel". http://www.republika.co.id/berita/nasional/daerah/17/01/31/oknabd28 2-makanan-tanpa-label-halal-mui-ditemukan-di-toko-ritel. Diakses tanggal 22 Januari 2018.

Yaqin Ainul, "Sejarah Sertifikasi Halal Di Indonesia", www.hidayatullah.com/kajian/sejarah/read/2017/01/18/109939/sejara h-sertifikasi-halal-di-indonesia-1.html. Diakses tanggal 25 April 2018. 